\title{
Usos del espacio público en Tzintzuntzan durante la Semana Santa
}

\author{
Uses of Public Space \\ in Tzintzuntzan during Holy Week
}

\author{
José Manuel Martínez Aguilar \\ (D) https://orcid.org/0000-0002-0114-1900 \\ Universidad Michoacana de San Nicolás de Hidalgo, México. \\ majmanuel999@hotmail.com
}

Resumen: En Tzintzuntzan, como en otros lugares de México, ciertos espacios que durante la mayor parte del año se usan para circular y para realizar las actividades paganas, adquieren en la Semana Santa un significado místico, cuando los pobladores convierten los espacios seculares en espacios sagrados que representan los lugares donde Jesucristo pasó sus últimos años de vida. La particularidad en esta ciudad michoacana es la manera en que estos espacios son creados y transformados con prácticas únicas cuyo origen se remonta a la época colonial. El atrio -conocido como el atrio de los olivos- se convierte simbólicamente el camino hacia el Gólgota, pero también las cruces del poblado y las casas donde se custodian los cristos antiguos se convierten en altares provistos de una gran significación ante las cuales los penitentes y los participantes de las procesiones se humillan durante sus recorridos del Viernes Santo.

Palabras clave: penitentes; espías; procesión; religiosidad popular; Santo Entierro.

Cómo cITAR: Martínez Aguilar, J. M. (2022). Usos del espacio público en Tzintzuntzan durante la Semana Santa. Secuencia (112), e1770. Dor: https://doi.org/10.18234/secuencia.v0i112.1770

CC 1 Esta obra está protegida bajo una Licencia Creative Commons Atribución-NoComercial 4.0 Internacional. 
Abstract: In Tzintzuntzan, as in other parts of Mexico, certain spaces used for most of the year to circulate and to carry out pagan activities acquire a mystical significance during Holy Week, when settlers convert secular spaces into sacred ones representing the places where Jesus Christ spent the last years of his life. A distinctive feature of this Michoacan city is the way these spaces are created and transformed through unique practices, whose origin dates to colonial times. The atrium -known as the atrium of the olive trees- symbolically becomes the road to Golgotha. The crosses of the town and the houses where the old statues of Christ are kept become altars imbued with great significance before which the penitents and members of the procession kneel during their Good Friday processions.

Keywords: penitents; espías; procession; popular religiosity; Holy Burial.

Recibido: 29 de julio de 2020 Aceptado: 9 de septiembre de 2020 Publicado: 21 de enero de 2022

$E_{s}^{n}$ n México, las prácticas solemnes que tienen lugar durante la Semana Santa en las calles y espacios religiosos son las que tienen mayor significación para los católicos, pues son un recordatorio del martirio, muerte y resurrección de Jesucristo. Aunque estas fueron importadas por los conquistadores españoles, es innegable que se aderezaron con elementos surgidos de la manera de ver y entender el mundo por parte de los habitantes originarios de Mesoamérica, por lo que en cada poblado a lo largo y ancho del actual territorio mexicano fueron adquiriendo distintos matices.

En Tzintzuntzan, algunas costumbres relacionadas con la Semana Mayor se han ido redefiniendo con el paso de los años, pero en su esencia se han conservado como en pocos lugares. Tal es el caso de los recorridos que efectúan los penitentes por distintos espacios del atrio y calles cercanas al exconvento franciscano de este lugar, para humillarse frente a los altares y cristos que pertenecieron a los antiguos barrios. También son singulares los recorridos que hacen los espías representando la búsqueda de Jesús de Nazaret por las calles de la ciudad, que se suman a la procesión del Santo Entierro, la procesión del silencio, el Vía Crucis y la escenificación de la crucifixión.

Esta ciudad fue, en el siglo XVI, uno de los más importantes centros de difusión del catolicismo de la provincia franciscana de San Pedro y San Pablo 
de Michoacán, donde se formaron y residieron numerosos y destacados frailes. Estos se encargaron de introducir en numerosos pueblos del occidente de Nueva España las prácticas religiosas encomendadas por la Iglesia católica y la corona española. Las prácticas relacionadas con la Semana Mayor se realizaban desde entonces y durante el periodo virreinal en el templo de San Francisco, la capilla de la Concepción -que después se convirtió en el templo de la Soledad-, el amplio atrio del conjunto conventual y el claustro del convento; pero también se extendían a las calles del poblado, respetando las cruces y capillas de los antiguos barrios congregados en el siglo XVI (Martínez, 2017b).

Es este trabajo se revisan cuáles son las prácticas efectuadas durante la Semana Santa en Tzintzuntzan y su posible origen, poniendo especial atención en la tradicional participación de los espías y los penitentes en la apropiación de los espacios públicos que durante momentos se convierten en escenarios donde se recrean los misterios del Triduo Pascual -la Pasión, Muerte y Resurrección de Jesucristo-. Se sustenta en la idea de que el espacio donde se realizan las actividades de esta semana se determina más por las prácticas sociales que por los elementos físicos que lo limitan. En concordancia con Lefrevre (2007), el espacio no es pasivo ni vacío sino un producto de las relaciones sociales. Estas relaciones adquieren distintos matices a lo largo del año, pero especialmente durante la Semana Mayor se convierten en representaciones teatrales y muestras de fe que dan realce a los lugares de culto, pero también dotan a determinados espacios seculares de una sacralidad llena de significados y códigos.

El principal instrumento para obtener información sobre estas prácticas fue la observación directa del fenómeno en la actualidad, pero también se revisaron documentos de archivo y bibliografía, donde se da cuenta de cuáles eran algunas de las prácticas de esta semana en distintos momentos. El análisis y contraste de la información obtenida ofrece una interpretación personal que no deja de estar sujeta a discusión.

\section{SEMANA SANTA EN TZINTZUNTZAN}

La Semana Santa es para los católicos el lapso más significativo del año, ya que se conmemora el sufrimiento, muerte y resurrección de Jesucristo. Es precedida por la cuaresma e inicia el domingo siguiente a la primera luna llena del equinoccio de primavera, cayendo entre el 22 de marzo y el 25 de abril. 
Es un periodo de intensa actividad litúrgica, que comienza el Domingo de Ramos, cobra mayor solemnidad el Jueves y Viernes Santos, para concluir el Domingo de Resurrección. Durante este periodo, la mayor parte de los habitantes de Tzintzuntzan participa en la organización litúrgica, representaciones teatrales o escenificaciones dramáticas, procesiones, penitencias, arreglo de casas, capillas y templo parroquial, o bien como espectadores. En días y horas específicas, las calles, el atrio de los olivos, el templo de San Francisco, el templo de Nuestra Señora de la Soledad, la capilla de la Concepción y el antiguo atrio del hospital, se convierten en un gran escenario.

El Domingo de Ramos se realiza una ceremonia que recuerda la entrada triunfal de Jesucristo a Jerusalén, cuando una muchedumbre lo aclamaba y tendía sus túnicas por donde pasaba. Para este evento, se reúnen frente a la capilla de Guadalupe, en la comunidad vecina de Ojo de Agua, el sacerdote de Tzintzuntzan, un grupo de jóvenes de la comunidad vestidos de israelitas y romanos, así como decenas de fieles que cargan palmas de tule en sus manos. La gente lleva a cabo una procesión por un camino antiguo a Tzintzuntzan, pasando por el barrio conocido como Yaguaro e incorporándose a la vía principal del pueblo -avenida Lázaro Cárdenas- donde se detienen para hacer una breve representación de la gente aclamando a Jesús de Nazaret. Continúan hasta llegar al frente del templo de San Francisco, donde son recibidos por más personas (véase mapa 1). Allí los actores representan a los comerciantes de Jerusalén, quienes venden animales vivos, ollas de barro, granos y otras mercancías, mientras los soldados romanos juegan a los dados y a las cartas. El personaje de Jesús agrede a los comerciantes y les tira sus mercancías por hacer de la casa de su "padre una cueva de ladrones" (Iglesias, 2003; Mateo, 21: 8). Después de la recreación de los pasajes del Nuevo Testamento, a las once de la mañana, la gente reunida ingresa al templo para participar de la misa donde se bendicen las palmas. El mismo domingo, la gente del pueblo visita las casas donde se tienen resguardadas las imágenes de cristos antiguos; una versión de la visita de las siete casas que se realiza en otras localidades el miércoles o jueves (véase mapa 2).

El Miércoles y Jueves Santo se lleva a cabo el singular recorrido de los espías. Un grupo de 40 jóvenes representan a los romanos que buscan a Jesús de Nazaret para apresarlo. Están vestidos de blanco, tienen la cara tapada con una capucha roja, sus cinturas están ceñidas con una faja roja y en lugar de calzado portan medias rojas de algodón (véase imagen 1). En años anteriores se los ha visto portar un vestido dorado y una capa roja, además de la 
Mapa 1. Recorridos de los espías y recorrido del Domingo de Ramos

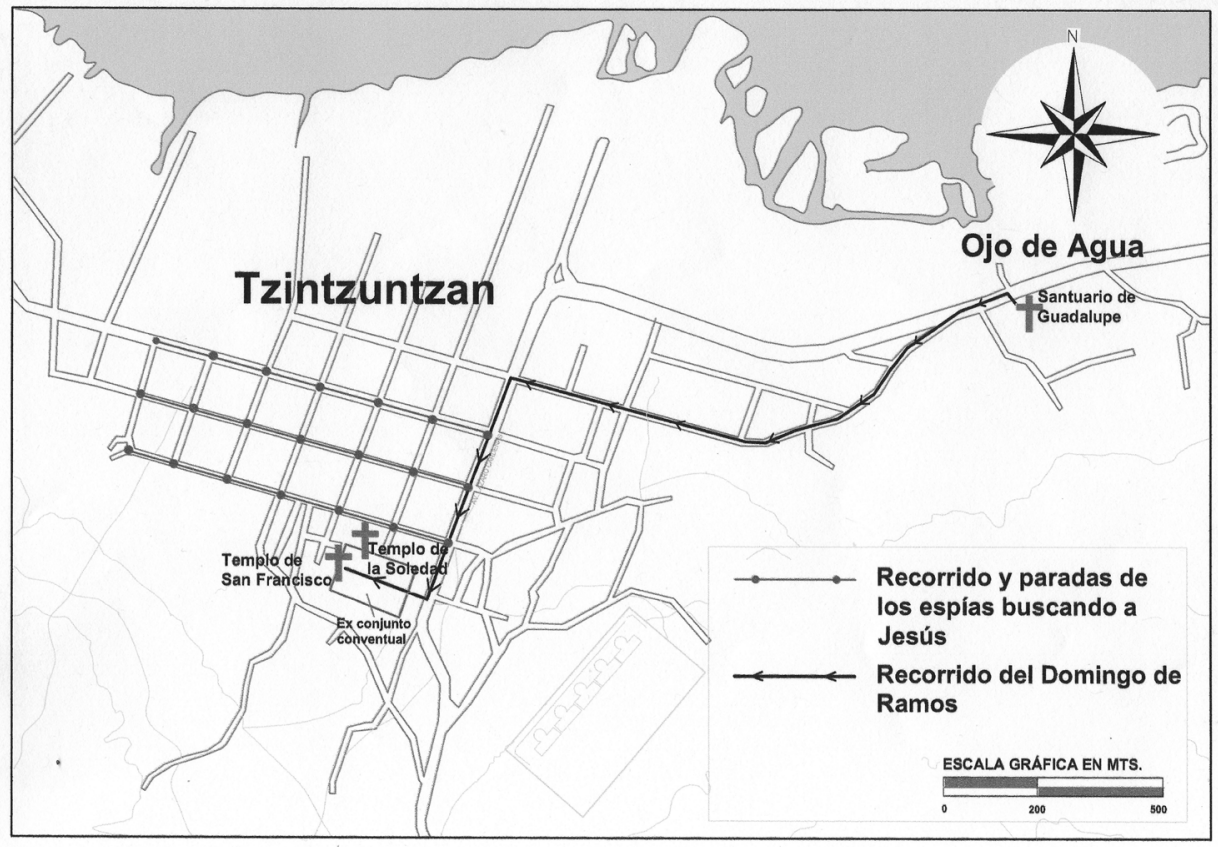

Fuente: elaboración propia. 
Mapa 2. Recorridos de penitentes de cruz y casas donde se resguardan los cristos

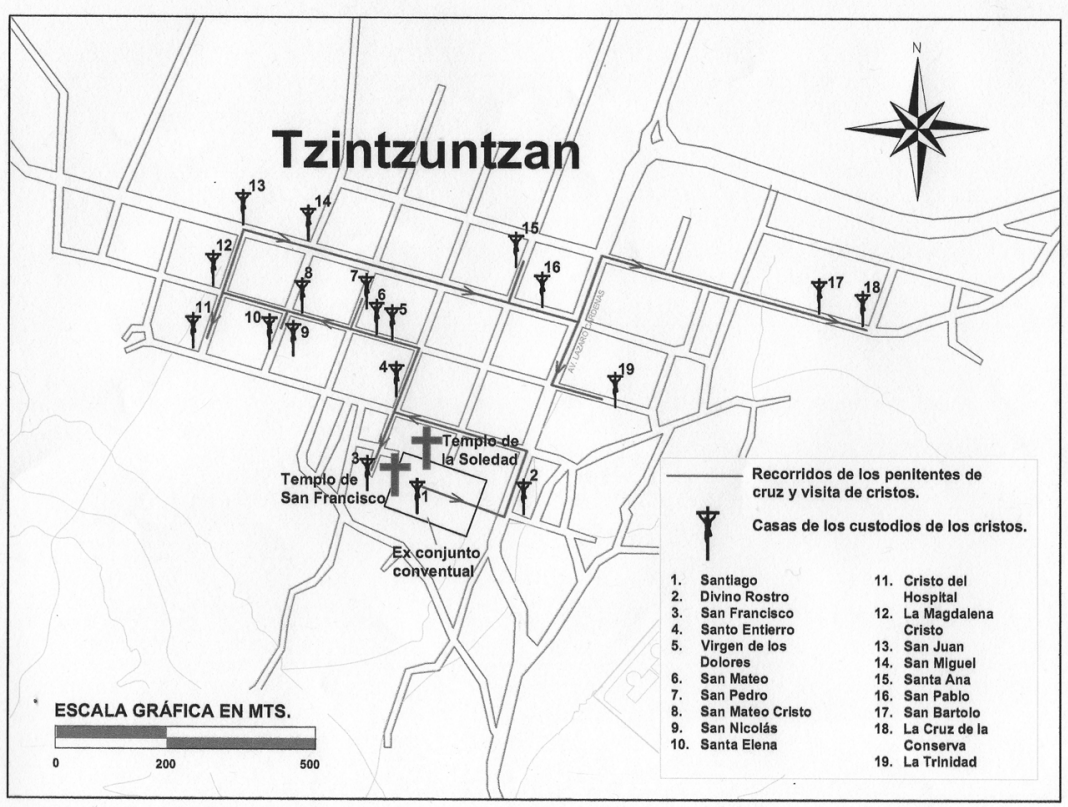

Fuente: elaboración propia.

capucha (Rodríguez, 2006). Los espías montan a pelo sus caballos y recorren tres calles paralelas entre sí, que van de oriente a poniente, deteniéndose por parejas en cada una de las esquinas y comunicándose con los demás al sonido de un silbato de barro. Este recorrido lo hacen varias veces, por más de seis horas, bajo los fuertes rayos del sol. El Jueves Santo continúan sus recorridos hasta las tres de la tarde, cuando cierran su participación visitando los cristos del siglo XVI que son resguardados en casas particulares (véase mapa 2). En unos pocos pueblos del país un espía vestido de romano toma lugar en la Semana Santa, pero el caso de Tzintzuntzan llama la atención por la cantidad de participantes y los recorridos tan coordinados y fuera de serie que realizan.

El Jueves Santo, desde temprano, un grupo de personas miembros de la comisión de los penitentes limpian unos antiguos grilletes -grillos- alre- 


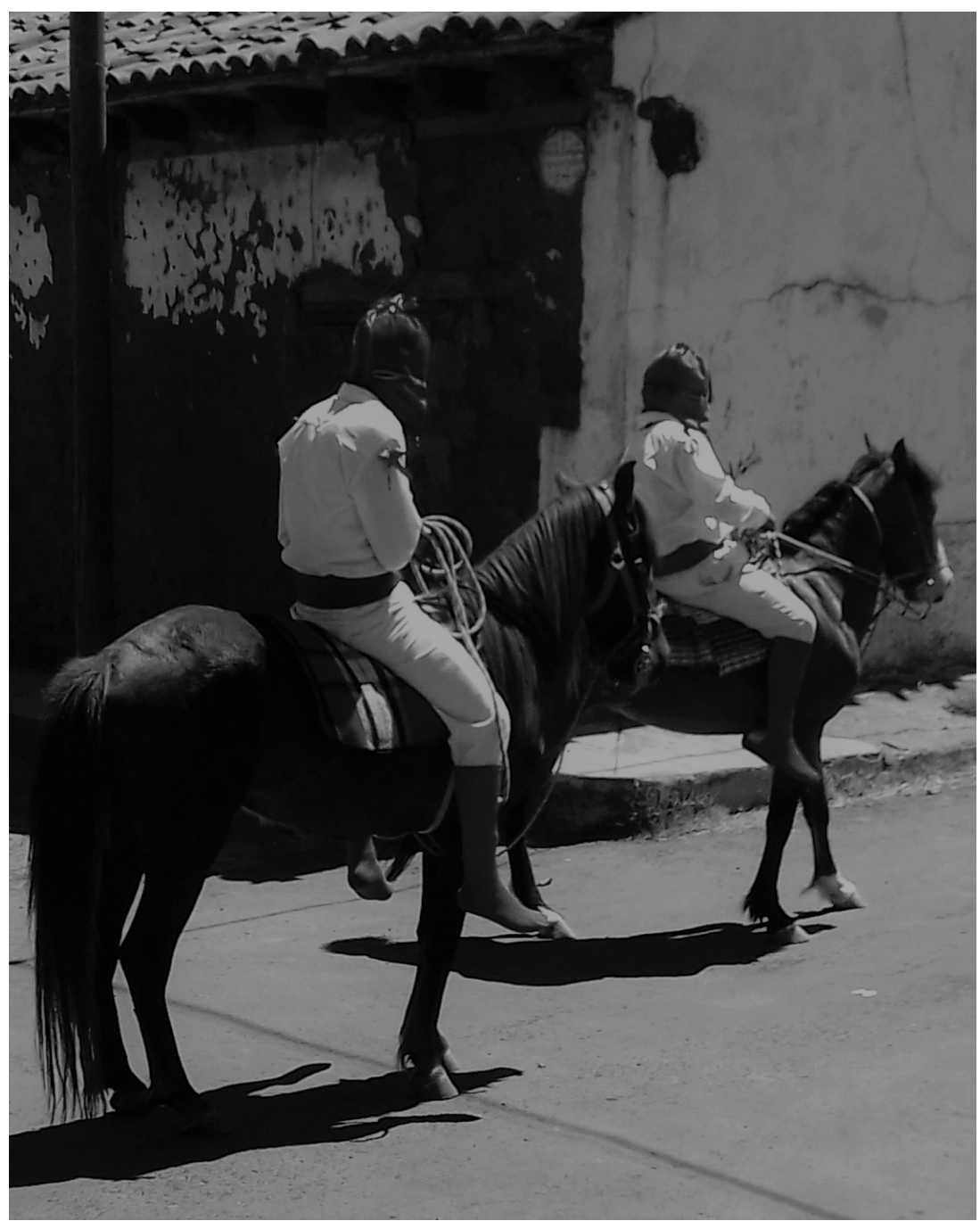

Imagen 1. Espías buscando a Jesucristo. Fotografía de José Manuel Martínez Aguilar.

dedor de la cruz del atrio del hospital, mientras que en la capilla abierta del otrora hospital de la Concepción un par de hombres de la misma comisión registran, dan turno y reciben una cooperación voluntaria de quienes participarán como penitentes al día siguiente. $\mathrm{Al}$ mismo tiempo, un grupo de 
cargueros colocan las imágenes de Dimas y Gestas frente al altar del templo de la Soledad. El Santo Entierro, un cristo de pasta de caña de maíz del siglo $\mathrm{XVI}$, se coloca recostado fuera de su urna, en medio de los dos sentenciados, y se bendicen sus reliquias. Todas las demás imágenes de este espacio y del templo parroquial están cubiertas con un paño morado en señal de luto. Mientras tanto, en el mismo recinto, algunos visitantes dan una limosna y se hincan frente al altar para que se les coloque una corona en la cabeza; acto seguido, una carguera de la Soledad ofrece una oración por ellos y hacer sonar una campanita. De fondo se escuchan saetas y se reza el rosario repetidamente.

En el antiguo atrio del hospital se improvisa un comedor para que los cargueros tomen sus alimentos, entre las largas jornadas del jueves y viernes. Entre tanto, frente a la capilla abierta del exconvento, los cargueros de la Judea y voluntarios de la localidad construyen un escenario y una jaula de madera donde encerrarán al joven que representa a Jesús. A las cinco de la tarde se realiza la ceremonia del lavatorio de los pies en el templo parroquial, en la que el sacerdote recuerda el gesto de humildad, amor y servicio a los semejantes que tuvo Jesús con sus discípulos.

Por la noche, los actores de la Judea escenifican misterios de la vida de Jesús, dando especial énfasis a la conmemoración de la institución de la eucaristía, la última cena, la oración del huerto y su prendimiento. Antes de subir al entablado se preparan y visten en un espacio al interior del exconvento. A pesar del frío, cientos de personas atestiguan la puesta en escena, que desde hace varios años se vale de luces y micrófono para matizar el drama. En ciertos momentos, la escenificación del prendimiento se extiende hacia el atrio, entre la gente, lo cual es ilustrativo debido a que el espacio se convierte en el huerto de los olivos donde Jesús fue aprehendido según el Nuevo Testamento (Iglesias, 2003; Juan, 18:12).

El Viernes Santo es el día donde se programan más actividades relacionadas con el Triduo Pascual. Desde temprano, los cargueros de la Soledad y sus familias adornan con telas, flores e imágenes religiosas cada una de las capillas del Vía Crucis. Por la mañana se celebra una misa y más tarde se siguen registrando a las personas que harán penitencia de grilletes o cruz. A continuación, entre 20 y 30 penitentes se desvisten, descalzan y se ponen un cendal en la cintura y una capucha blanca que les cubre el rostro. Se colocan los grilletes en los tobillos y un lazo atado en las muñecas, que se extiende hacia el centro de la barra de los grilletes. Apoyados por dos "cirineos", que son familiares o amigos. Avanzan lentamente, dando pequeños saltos por el 
atrio, durante dos horas aproximadamente. Hacen paradas frente a los espacios más simbólicos del lugar: la capilla del hospital de la Concepción, los restos de la capilla de la Tercera Orden, el templo de San Francisco, la cruz atrial y la imagen del Santo Entierro, que se encuentra dentro del templo de la Soledad. En todos los lugares se arrodillan un breve momento para rezar misterios, siguiendo las cuentas de un rosario que portan en una de sus manos. En la otra mano cargan un plato para recibir limosna y reunir cierta cantidad prometida que entregarán a la iglesia (véanse mapa 3 e imagen 2). Otros creyentes, que pueden ser del pueblo o peregrinos, recorren arrodillados los caminos empedrados del atrio hasta llegar a la puerta del templo de la Soledad, donde se encuentra la imagen de Cristo en su urna -Santo Entierro-. Para que no se desgarren las rodillas, sus familiares les colocan cobijas o cartones por donde van pasando.

El Vía Crucis representa el recorrido que hizo Jesús de Nazaret hacia el calvario, donde sería crucificado, para recordar a los fieles que el hijo de Dios entregó su propia vida para salvar al mundo. Comienza a mediodía, cuando Jesús, encarnado por un joven de la comunidad, es presentado ante Poncio Pilatos y ante el sanedrín; para ser juzgado y condenado a morir crucificado. El recorrido se lleva a cabo en el atrio, sobre un camino empedrado, siguiendo una dirección contraria a las manecillas del reloj. En la procesión Jesús va al frente, cargando una pesada cruz y recibiendo azotes de varios soldados romanos. Participa también el centurión, quien hace una manda representando al soldado romano que encajó una lanza en el costado de Jesús. Este aparece por primera vez el Viernes de Dolores, montando un caballo, portando un vestido blanco, gorro puntiagudo y un velo sobre la cara. El personaje misterioso sujeta en su mano derecha una lanza con el letrero de INRI. En el recorrido no faltan los encargados de tocar la chirimía y el tambor, respectivamente, un cargo vitalicio que es heredado de generación en generación. Estos sonidos son emitidos en los momentos trágicos del prendimiento, el Vía Crucis y la crucifixión. La Virgen María y María Magdalena lloran desconsoladas a su lado. Los soldados romanos lo golpean y humillan, ante la mirada de un grupo de actores que caminan detrás y del resto de los espectadores. El sacerdote del pueblo marcha también en la procesión, haciendo una pausa en cada una de las capillas que representan las estaciones de la Pasión, para narrar los misterios y liderar los rezos y cánticos. En la tercera, séptima y novena estación, Jesús cae; en la última, el actor termina su participación y deja su lugar a la imagen del Santo Entierro. 
Mapa 3. Recorridos de los penitentes de grillos y circuito del Viacrucis

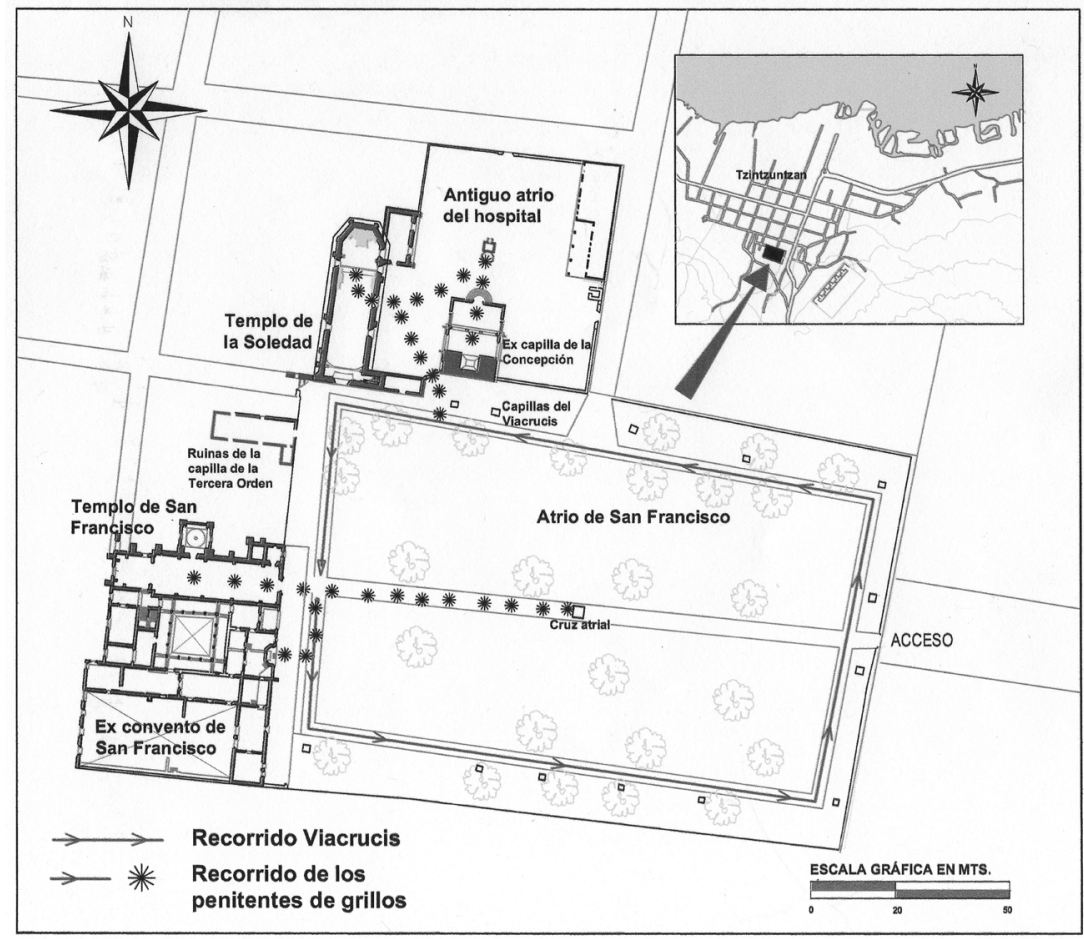

Fuente: elaboración propia.

Dentro del templo de la Soledad se colocan las imágenes de los crucificados Dimas y Gestas. El Santo Entierro, una imagen de Jesucristo que yace en un féretro transparente, es sacado de su féretro y, debido a que sus brazos son articulados, es crucificado y situado en medio de las otras dos imágenes. Este evento va seguido de la representación de las Siete Palabras, y sólo unos minutos después se realiza la representación del descendimiento. Esta ceremonia es muy significativa y sentida para muchos fieles, varios de los cuales lloran y se lamentan como si la muerte del hijo de Dios fuera real. No es de extrañarse, pues, el misterio del descendimiento ha sido muy respetado en este lugar. Desde la época virreinal dos importantes imágenes recordaban este momento: uno de ellos era el lienzo del Descendimiento, que se había atribuido 


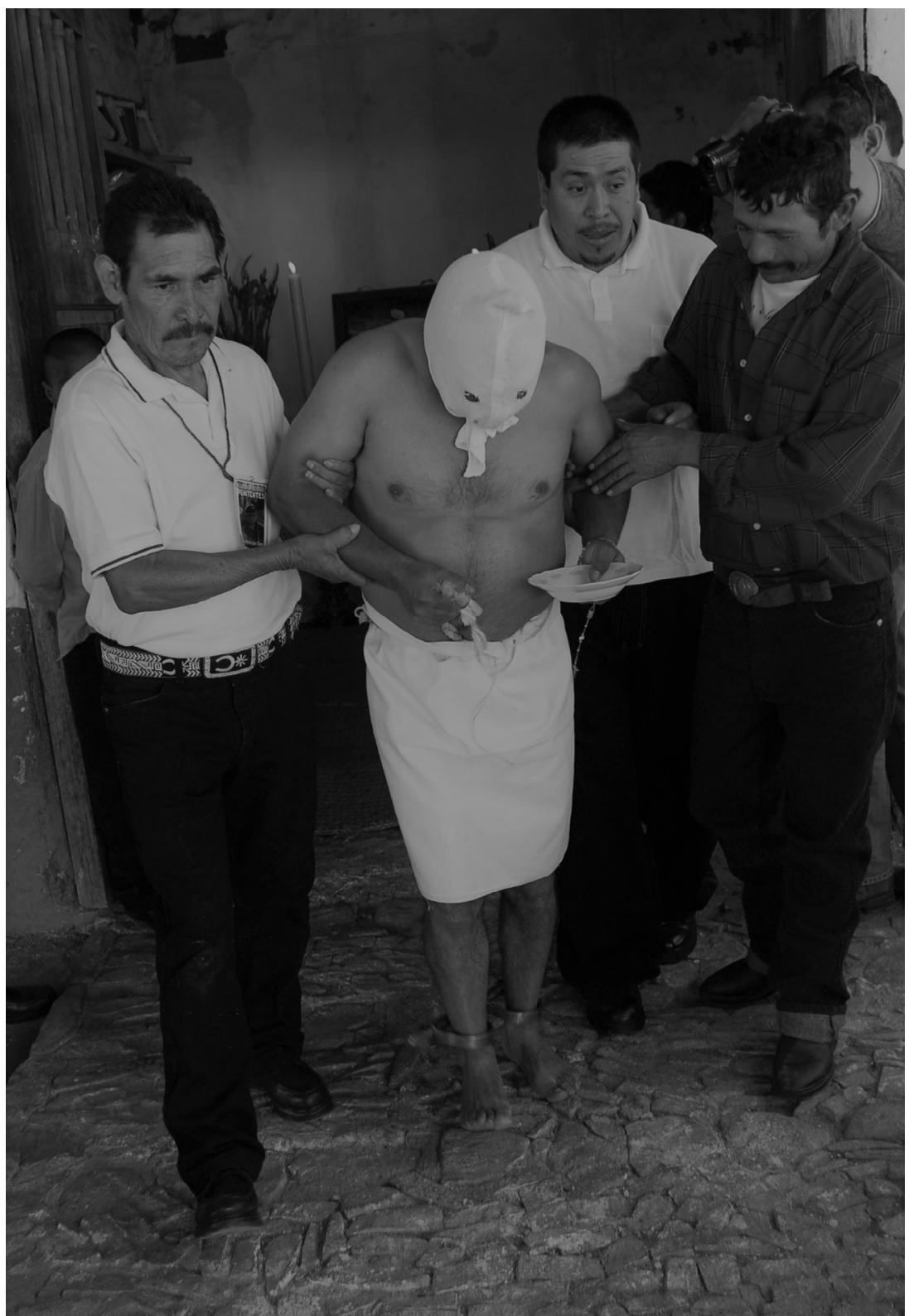

Imagen 2. Penitente de grillos auxiliado por dos cirineos. Fotografía de Angélica Ayala. 
a Tiziano -desaparecido en 1943-; el otro era el relieve de pasta de caña de maíz, con el mismo tema, que hasta hace poco tiempo se encontraba en el crucero del claustro debajo del exconvento (Martínez, 2016a). Regresando a las actividades del Viernes Santo, a las cinco de la tarde se realiza la celebración de los Santos Oficios Litúrgicos y la adoración de la cruz en el templo de la Soledad.

Después del Vía Crucis, catorce cristos elaborados con pasta de caña en el siglo XVI, son llevados al atrio y posados entre el templo de la Soledad y el templo parroquial. De acuerdo con la tradición oral, en la época colonial Tzintzuntzan estaba formado por nueve barrios; cada uno de ellos contaba con su propia capilla y sus respectivas imágenes que habían llevado consigo cuando fueron congregados. Las sacaban únicamente para la procesión del Santo Entierro, que se realizaban por el atrio y las principales calles de la ciudad los Viernes Santos. Según Rendón (1996, pp. 225-227), se trataba de los barrios de Santa Ana, La Magdalena, San Mateo, San Pablo, San Juan, Santo Santiago, San Bartolomé, San Miguel y La Santísima Trinidad. Por su lado, Carrillo Cázarez (1992, p. 102) indica que los barrios en 1569 eran San Bartolomé, San Pablo, María Magdalena, Yaguaro, Zanambo, Cerandangacho, San Mateo, San Lorenzo e Higuatzeo. De cualquier manera, los cristos actuales corresponden a los nombres que menciona Rendón, además de los cristos de Santa Rita, San Pedro y San Nicolás, que suman un total de catorce. ${ }^{1}$

$\mathrm{Al}$ caer la tarde se realiza la importante procesión de la sagrada imagen del Santo Entierro, la cual sale del templo de la Soledad por la puerta noroeste. Al frente, tres cargueros llevan en sus manos símbolos de la Pasión. Son seguidos por ocho cargueros que llevan en hombros la Sagrada Imagen del Santo Entierro; atrás va la imagen de la Virgen de la Soledad, una Dolorosa, tres ángeles vestidos de negro y los catorce cristos de los antiguos barrios. La procesión avanza por las calles del pueblo, pasando por las cruces del poblado y por las casas donde se resguardan los cristos de los antiguos barrios. Después se incorporan a la avenida principal y regresan al templo

${ }^{1}$ Desconocemos el origen del cristo de Santa Rita, pero al parecer el de San Nicolás estuvo dentro de una capilla levantada en el siglo xviII frente al exconvento, como lo revela un documento: "y también una capilla de San Nicolás que está en el cementerio [...] tiene dos imágenes de San Nicolás, una de vara y cuarta y otra de San Nicolás penitente; un crucifijo de vara y cuarta y unas andas del santo", Secularización de la doctrina y curato de Tzintzuntzan, 1762-1767. Fondo diocesano. Sección gobierno. Serie religiosos. Subserie franciscanos. Caja 275, exp. 142, f. 36. Archivo Histórico Casa de Morelos (en adelante AнCM), Morelia, Michoacán, México. 
de la Soledad. Mientras esto sucede, una gran cantidad de gente acompaña la imagen o la observa pasar, guardando silencio. En la procesión también participan decenas de personas cargando cruces de madera. Terminando la procesión se vela al Santo Entierro, para lo cual varios cargueros y gente del pueblo cantan y hacen oración toda la noche. Durante la procesión, tanto la gente que participa caminando alrededor del atrio, como la que observa, guarda silencio absoluto. Únicamente se escuchan murmullos de unos pocos niños y adultos imprudentes.

Por la noche, decenas de penitentes cargan en sus hombros cruces de madera de más de tres metros de largo y hacen un recorrido por las calles de Tzintzuntzan, siguiendo códigos no escritos, que sólo los habitantes del lugar que los conocen transmiten a los nuevos penitentes: los que cumplen su primer año de penitencia salen por la puerta poniente del exconjunto conventual y caminan en el sentido de las manecillas por las calles, para terminar en el punto de salida; los que verifican su último año de penitencia salen por la puerta oriente y hacen el recorrido en sentido opuesto a las manecillas del reloj. En su recorrido son acompañados por dos personas; los tres visitan una serie de cruces, previamente adornadas con telas moradas y blancas, flores, un altar con veladoras y a veces una imagen religiosa. Los penitentes sueltan la cruz y los acompañantes la tienen que sostener; si se cae la cruz o el penitente, los tres tendrán que iniciar de nuevo el recorrido. Se detienen unos segundos frente a cada altar, se hincan y hacen una breve oración, se levantan y se azotan la espalda cuatro o cinco veces, mientras hacen una especie de baile ritual de unos tres segundos. Una vez hecha esta ceremonia corren por las calles oscuras con la cruz cargada, hasta la siguiente parada (véase mapa 2 e imagen 3). Debe advertirse que ciertas disciplinas -látigos- que utilizan suelen ser casi inofensivas, pero otras están provistas de pequeños clavos que causan serias laceraciones en la piel y hacen sangrar la espalda.

Al mismo tiempo, decenas de penitentes "de grillos" caminan por el atrio y se detienen en los lugares provistos de mayor valor simbólico, antes mencionados, mientras se flagelan las espaldas con el fin de pagar sus faltas y recibir los favores de la imagen del Santo Entierro. Si se encuentran dos penitentes, se saludan con una reverencia. A las doce de la noche se efectúa la procesión del silencio alrededor del atrio, en la cual la gente camina acompañando la imagen de la Dolorosa en sentido contrario a las manecillas del reloj.

El Sábado Santo es un día de dolor y tristeza destinado a guardar luto y hacer reflexión, pero también es llamado Sábado de Gloria porque en 


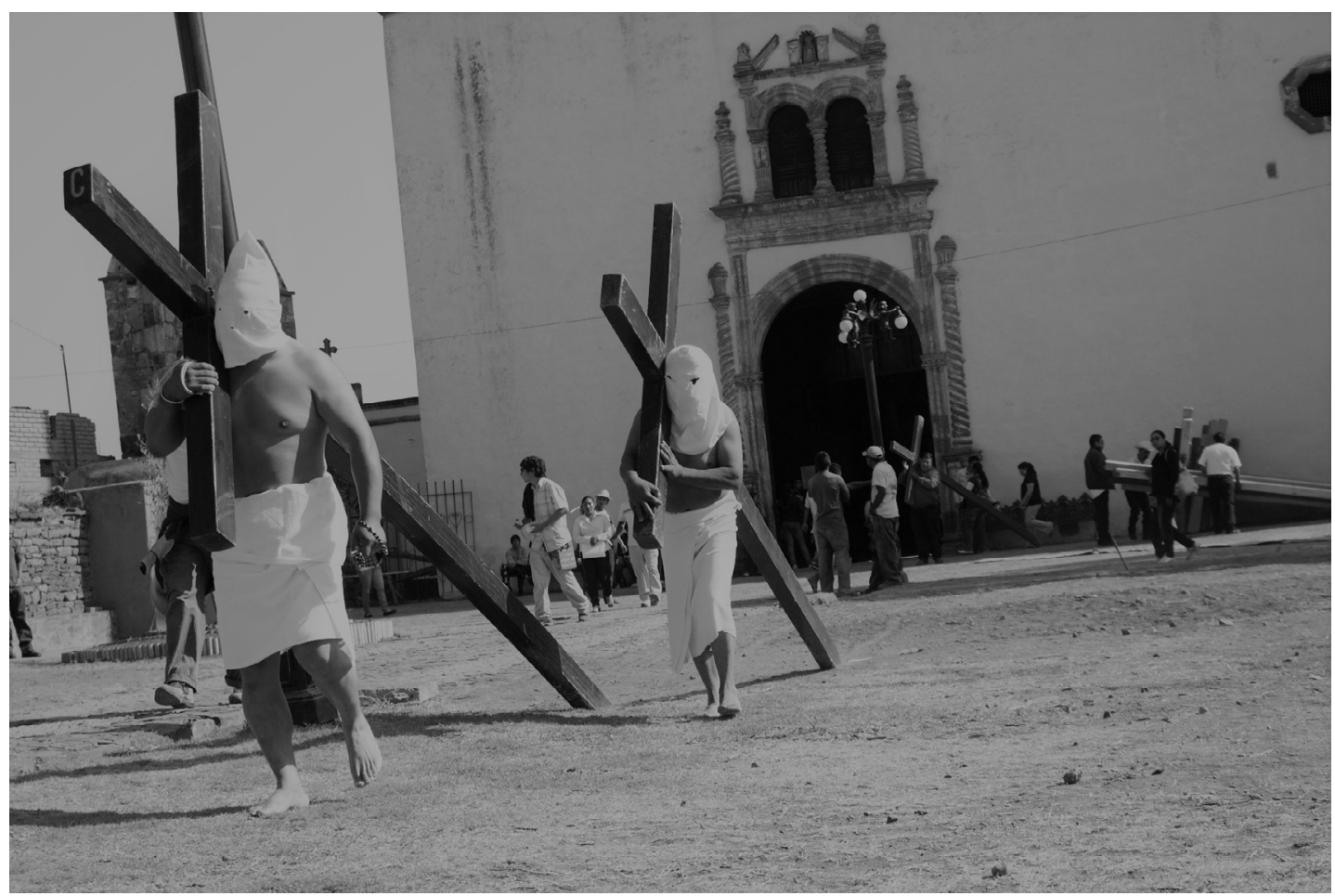

Imagen 3. Penitente de cruz. Fotografía de Angélica Ayala. 
la noche se conmemora la apertura de la gloria. Al medio día se reflexiona sobre los siete dolores que experimentó la Virgen María durante la Pasión de Cristo. Esta ceremonia se conoce como Vía Matris, que significa camino de la madre. Desde la mañana los cristos antiguos son expuestos en el templo de San Francisco y por la noche se efectúa solemnemente la Vigilia Pascual. Es la celebración del Santo Oficio, que inicia dentro del templo a oscuras; luego, el sacerdote bendice el Fuego Nuevo, bendice los óleos sacramentales y enciende el Cirio Pascual que simboliza a Cristo Resucitado; se hace una procesión dentro del templo; por último se celebra la Liturgia de la Palabra y se entona el Gloria; repican las campanas que habían estado silenciadas por dos días, los paños morados que cubrían el lienzo del Señor del Rescate y el resto de imágenes son retirados en señal de apertura de la Gloria, y se efectúa la Liturgia Bautismal. Por la noche, después de que fue paseado por el poblado, se quema en la plaza principal un muñeco de trapo que representa a Judas. Con este evento concluye el Triduo Pascual.

La Semana Santa concluye el Domingo de Resurrección, con la celebración de varias misas donde se recuerda cómo Cristo venció a la muerte, el evento más significativo de la religión católica, por lo que se invita a la reflexión personal y al rescate de valores. En la casa de quien fungió como Centurión se ofrece una cena con pozole de haba y se elige a los nuevos cargueros para el año siguiente (Rendón, 1998, p. 40).

\section{PENITENTES DE SANGRE Y DE LUZ}

De todas las prácticas efectuadas en la Semana Santa en Tzintzuntzan, las que llaman la atención de manera destacada, debido a su singularidad, son las que llevan a cabo los penitentes dentro del exconjunto conventual de San Francisco y por las calles de la ciudad. Su origen parece remontarse a la época colonial, posiblemente a las primeras décadas de la conquista espiritual en los territorios de América adheridos a la corona española, cuando los religiosos introdujeron celebraciones y conmemoraciones cristianas permitidas por la Iglesia, teniendo como modelo las que se realizaban en España. Muchas de ellas, como las que tenían lugar durante la Semana Santa, se convirtieron en escenificaciones dramáticas que permitían enseñar a los nativos los misterios, de manera más comprensible, suplantando o fundiéndose con las prácticas precortesianas de los nativos (Ricard, 1992, p. 339). 
En Nueva España, la celebración de la Semana Santa, como el resto de las fiestas de carácter religioso, era organizada y efectuada en su mayor parte por las cofradías y hermandades católicas de españoles, indios y mulatos. Las cofradías llamadas de sangre o disciplina eran las más reconocidas, puesto que sus miembros realizaban procesiones por las calles y atrios de los templos, descalzos con las cabezas cubiertas con capuchas -capirotes-, mientras se autoflagelaban las espaldas desnudas con disciplinas -látigos- o cargaban pesadas cruces.

Una de las evidencias más antiguas que se tienen sobre la manera en que se efectuaban las procesiones en Nueva España son las pinturas de los muros del exconvento franciscano de Huexotzingo, Puebla, que datan del último cuarto del siglo xvi. En ellas se pueden ver disciplinantes cubiertos con capirotes, azotándose las espaldas. Algunos de ellos portan un rosario y otros exhiben los símbolos de la Pasión de Cristo. Se cree que estas pinturas representan la procesión del silencio que hacían los miembros de la cofradía de la Veracruz en la Semana Santa (Palomero, 1981; Verdi, 1995).

La descripción que hace Torquemada (1983) de una procesión efectuada un Jueves Santo de 1609 en la ciudad de México es elocuente. Dice que en la capilla de San José de los Naturales "se juntan allí todos los indios de las cuatro cabeceras, y de allí salen azotándose con 219 insignias de Cristo y otras de su Pasión [...] Por esta misma forma hacen sus procesiones en todos los pueblos grandes de esta Nueva España [...] y más gente irá en la de Tlaxcala; a lo menos en su tiempo salían quince y veinte mil disciplinantes" (vol. III, p. 229). En estas procesiones de sangre, conocidas también como flagelantes o de penitencia, dice López de Gómara (2007), llegaban a marchar "diez mil, cincuenta mil y hasta cien mil disciplinantes” (p. 479), un número sorprendente, en comparación con lo que se ve en la actualidad. Benavente (1979) dice que

El Jueves Santo es muy de ver aquí en México [...] en una parte son cinco o seis mil, y en otra diez y doce mil, y al parecer de españoles en Tetzcoco y en Tlaxcallán parecen quince o veinte mil; aunque la gente puesta en posesión parece más de lo que es [...] unos se disciplinan con alambre, otros con cordel [...] y muchos Españoles he visto ir llorando y todos ellos van cantando el Pater Noster y Ave María, Credo y Salve Regina (p. 73).

Un testimonio más sobre las procesiones que se realizaban en la ciudad de México con motivo de la Semana Santa es el que ofrece el italiano Juan 
Francisco Gemelli Careri, quien dice que el Jueves Santo de 1697 presenció tres procesiones precedidas por la cofradía de la Trinidad, los cófrades de la iglesia de San Gregorio de los padres de la Compañía y la cofradía de San Francisco, quienes llevaban imágenes y luces. Narra también que el Viernes Santo salió la procesión de negros e indios, hermanos de la cofradía de Santo Domingo, con muchas personas que se disciplinaban y hacían otras penitencias. A esta procesión siguió la de los españoles, los caballeros de hábito y cófrades, entre los que iban diez disciplinantes con larguísimas caudas (Torre, 1971, pp. 416-417).

Entre las distintas procesiones que se efectuaban en Nueva España, la de penitentes, que hacían su aparición el Jueves o Viernes Santo de cada año, era la que tenía más éxito, por el dramatismo que transmitía a los espectadores y por el simbolismo que tenía para los creyentes católicos. Esta costumbre implicaba la autocondena, con el fin de pagar los pecados cometidos, como sacrificio para obtener auxilio del Santísimo, como agradecimiento por haber recibido favores, o como señal de contrición por el sufrimiento que experimentó Jesucristo por causa de los hombres.

El afán de los primeros frailes por convertir a los indios a la nueva religión y alejarlos de costumbres que no se adecuaran al modelo cristiano los llevó a administrar justicia por su cuenta, aplicando muchas veces castigos físicos o poniendo como penitencia la autoflagelación para redimir los pecados, lo que consideraban parte de sus obligaciones como educadores (Urquiza, 1993, p. 41). En el mismo tenor, la Real Audiencia emitió una serie de ordenanzas en 1539 para aplicar castigos severos a quienes se resistieran al cambio cultural; por ejemplo, quienes faltaban a las misas se les daban seis azotes sobre la ropa, a quienes caían en idolatrías los detenían, los ataban y los llevaban al convento, donde tenían que hacer penitencia, aprender la doctrina cristiana, ir a maitines y azotarse a medianoche. Este castigo duraba varias semanas, hasta que quedaban suficientemente arrepentidos (Wright, 1998, pp. 52-53).

También, como parte de la evangelización de los nativos americanos, los religiosos mendicantes les enseñaron, sobre todo a partir del Concilio de Trento, el rito de la confesión, una de las tres partes del sacramento de la penitencia, y los convencieron de la necesidad de que se reconocieran culpables de sus faltas, de lo contrario serían condenados eternamente (Martiarena, 1999, p. 144). Entre los mismos frailes, la autodisciplina física era parte común del ritual para expiar culpas, y los indios pronto la adoptaron como medio pro- 
pio para redimir las propias, pedir favores o agradecer bendiciones, tal vez, dice Warren, debido a la práctica que tenían algunos grupos de nativos americanos de sangrarse por devoción y hacer sacrificios humanos para ofrecer la sangre a su Dios (Warren, 1997, p. 102).

Las prácticas de autocastigo físico fueron comunes en toda Nueva España durante dos siglos y medio, hasta que en 1783 el rey Carlos III promulgó una Real Orden que prohibía enérgicamente, en las procesiones de Semana Santa que se celebraran en sus reinos, la asistencia de penitentes de sangre, empalados y otros espectáculos ajenos al espíritu religioso que les impulsó (Palomero, 1981, p. 115). Ya desde años atrás se había prohibido salir en las procesiones públicas casi desnudos e indecentes, con el rostro cubierto o túnicas, ${ }^{2}$ y continuamente se insistía en que se cuidaran los escotes, la profanidad de vestimentas y se evitaran las procesiones nocturnas. Luego se prohibió la venta de alimentos y bebidas por donde pasaran las procesiones y en las inmediaciones de los templos. ${ }^{3}$ En el caso de Tzintzuntzan creemos que era habitual la práctica de la autoflagelación. En esta ciudad estaba el convento sede de la Custodia de San Pedro y San Pablo de Michoacán y un importante noviciado; ahí residieron algunos de los franciscanos observantes más influyentes del occidente de Nueva España, quienes acostumbrados al rito de la penitencia corporal, debieron influir en los indios para que siguieran el ejemplo. Incluso es sabido que en el último cuarto del siglo xvi sus habitantes fabricaban látigos, conocidos también como disciplinas, lo que sugiere que eran de uso común. Dice Ciudad Real (1976) que es "aquel pueblo de gran vecindad de indios tarascos [...] Hácense allí en toda aquella guardianía, trompetas y chirimías [...] y hácense muy buenas cuerdas y disciplinas; todos andan bien tratados y son muy devotos de nuestro estado" (p. 76).

Es evidente que no todas las procesiones que describen los cronistas eran de penitentes. Desde luego que eran comunes las procesiones realiza-

${ }^{2}$ Obispo de la catedral de Michoacán recomendándole cuide lo dispuesto sobre el abuso de los escotes, profanidad de trajes y procesiones de noche en la Semana Santa. 26 de marzo de 1867. Reales cédulas originales. Vol. 241, exp. 43, f. 89. Archivo General de la Nación (en adelante AGN), México.

${ }^{3}$ Real orden para que en las procesiones de Semana Santa nadie pueda poner puestos de chías, almuerzos, frutas, dulces, ni otro comestible en las calles por donde transitará la procesión. 1789. Indiferente virreinal. Caja 4954, exp. 019, 5 fs; Bando prohibiendo la venta de comestibles, bebidas y juguetes en las calles por donde transitan y en las inmediaciones de los templos. 23 de marzo de 1790. Instituciones coloniales. Gobierno virreinal. Bandos 11. Vol. 15, exp. 54, f. 156. AGN, México. 
das para la fiesta de Corpus Christi, o las que efectuaban las cofradías para pedir por los difuntos. Entre todas, las llamadas procesiones de luz fueron las más comunes en la época virreinal; en ellas los fieles marchaban con una vela en la mano, vestidos de luto, cargando imágenes de bulto relacionadas con la Pasión de Cristo, y durante el recorrido se detenían en altares para hacer oración o rezar misterios con el acompañamiento de saetas y alabanzas (Rea, 1643, pp. 84-85). Según fray Juan de Grijalba, prior del convento de San Agustín de México, en 1624 las procesiones salían en la cuaresma llevando sus miembros cirios, pasos y estandartes, de acuerdo con la costumbre española; sin embargo, aunque los españoles fueron aficionados a las procesiones, los indios venían a resultar en este punto sus maestros, dice el autor de la Crónica de la Orden de N. P. San Agustín en las provincias de Nueva España (Palomero, 1981, p. 315).

La mayoría de los recorridos se realizaban por las calles, los grandes atrios de los conventos y templos, e incluso los claustros. Al respecto, fray Alonso de la Rea, miembro de la orden franciscana, escribió que desde 1520 se llevaban a cabo procesiones tanto por los claustros como en los patios de los monasterios -cementerios, ahora llamados atrios-. Los nativos, generalmente miembros de cofradías de Ánimas u oficiales, conformaban el grupo de fieles que desfilaba por el claustro cantando responsos y siguiendo la procesión dirigida por los frailes. En Tzintzuntzan hay evidencia de que en el siglo XVIII las cofradías de Ánimas y del Santo Entierro hacían procesiones en el atrio y utilizaban las capillas posas -ahora desaparecidas- como estaciones, pero también se sabe que caminaban alrededor del claustro debajo del convento, donde se veneraban imágenes de la pasión de Cristo (Phillips, 1999, p. 237). En los cruceros, que servían de estaciones, los devotos se detenían por un momento y hacían sus plegarias. Ahí se encontraban representaciones de "cuatro hermosísimos lienzos romanos de la Oración del Huerto, el Señor de la Columna, el Ecce Homo y la Crucifixión, todos cuatro con sus marcos de madera pintados de negro". "Los ángulos esquineros, debajo de la viguería, eran decorados por unos alfarjes de lacería de madera y piñas, "donde se recurrió a la herencia mudéjar de armaduras decoradas con geométricos lazos

${ }^{4}$ Secularización de la doctrina y curato de Tzintzuntzan. 1762-1767. Fondo diocesano. Sección gobierno. Serie religiosos. Subserie franciscanos. Caja 275, exp. 142, f. 82 . AHCM, Morelia, Michoacán, México. 
a fin de proveer la necesaria aura y significación demandada por la hostia" (Phillips, 1999, p. 249).

En el caso de la cofradía de las Ánimas del Purgatorio de Tzintzuntzan se sabe por sus estatutos que los miembros activos tenían obligación de realizar una misa el último viernes de cada mes y todos los viernes de Cuaresma, asumir los gastos del sacristán y cantores, ocuparse de que se dijeran misas para la salvación de las almas de los difuntos y, durante la Semana Santa, realizar procesiones por el atrio y el claustro del convento (Bechtloff, 1996, pp. 104-106). No obstante, en las referencias que se tienen no dicen que las procesiones fueran de sangre ni que los recorridos se hicieran por las calles. Lo que se sabe es que en 1725 se fundó en el convento de Tzintzuntzan la hermandad de la Tercera Orden de Penitencia, formada por españoles radicados en la ciudad y en haciendas cercanas. ${ }^{5}$ Es probable que esta fraternidad sí participara activamente en las procesiones de sangre y de luz durante la Semana Santa hasta su extinción, después de 1766 (Martínez, 2017a, p. 48).

Tanto la cofradía del Santo Entierro, como la de Nuestra Señora de la Soledad y Ánimas del Purgatorio tenían su sede en la capilla del hospital de la Concepción. En el siglo XVII, la advocación cambió por la de Nuestra Señora de la Soledad, lo que explica por qué algunas de las prácticas que realizan los cargueros de la Soledad tienen similitud con las que llevaban a cabo los cargueros del hospital, principalmente las que tienen lugar durante la Semana Santa, y por qué ceremonias como la crucifixión, descendimiento y velación de Jesucristo, que estaban relacionadas con las cofradías del hospital, se celebren dentro del templo de la Soledad y no en el templo parroquial de San Francisco (Martínez, 2017a).

En la actualidad la procesión de los cristos y la del Silencio, en las cuales participa prácticamente todo el pueblo, son de luz. Los penitentes no forman parte de las mismas, sino que hacen sus recorridos de manera individual, como ya se ha dicho. Y aunque no hay evidencia contundente de la presencia de penitentes en la época colonial, creemos que ya existían desde ese tiempo. Por lo pronto, la referencia más antigua que conocemos es de 1900, gracias al testimonio de Bruce Johnstone (1901). Cuando este viajero estadu-

${ }^{5}$ Fray José Díaz de Prado concede licencia para que en la iglesia del Convento puedan tener sus ejercicios según el tenor $y$ forma que ordenan las constituciones y asigna el estipendio que deben pagar por las misas y fiestas que tienen obligación de hacer en el año. Juan de Guevara. 21 de febrero de 1725. Fondo xxviII. Leg. 212. Carpeta 7, doc. 1, f. 2. Centro de Estudios de Historia de México Carso (en adelante ceHM Carso), México. 
nidense visitó Tzintzuntzan, un Jueves Santo, pudo ver a unos penitentes que se arrastraban hacia el templo con una corona de espinas en su cabeza y estaban llenos de moretones y marcas de flagelaciones. Otros penitentes estaban cubiertos de sangre y los grillos en sus tobillos habían hecho tanto daño que parecían revelar los huesos. Aun con lo dramáticas que son estas prácticas, hay quienes aseguran que en el pasado los daños que se infringían los penitentes eran mucho más severos que en la actualidad; incluso, previo a su participación por las calles o atrio, los penitentes tenían encierros de varios días, donde meditaban, ayunaban y se disciplinaban en silencio (Rendón, 1998 , p. 21). Foster (2000, p. 299) dijo ser testigo de cierta teatralidad y artificio en el daño que se hacían lo penitentes y aseguró que en el pasado los hombres quedaban tan heridos que tenían que guardar cama por varias semanas, como lo atestiguó Johnstone. Según Palomero (1981, p. 316), era común que los penitentes que terminaban su recorrido, ingresaban a uno de los espacios del hospital de indios o a una de las capillas, donde les tenían preparadas vasijas grandes con agua caliente y ají, o vino hervido, arrayán en polvo, laurel, rosas, violeta y romero para que se lavaran las heridas. En la actualidad no se curan las heridas, pues se tiene la fe de que Cristo los sanará.

\section{USOS DEL ESPACIO EN LA SEMANA SANTA. ENTRE LO SAGRADO Y LO PAGANO}

El espacio público en Tzintzuntzan se transforma constantemente durante todo el año con prácticas cotidianas y rituales. Se configura físicamente con elementos tangibles que son claramente reconocibles, como calles, plazas, casas, elementos naturales y límites geográficos; además de hitos, algunos de ellos de uso mixto, como el atrio, o claramente de carácter litúrgico, como el templo, capillas, cruz atrial, cruces de barrios y altares. Sin embargo, el espacio se determina más por las prácticas llevadas a cabo en un determinado lugar que por los elementos físicos que lo limitan.

De acuerdo con Certeau (2007), el espacio es un lugar animado por un conjunto de movimientos y acciones que en él se despliegan; es existencia, es un lugar "practicado", lo que implica que son los habitantes quienes hacen y transforman el espacio (p. 129). En este mismo sentido, Lefrevre (2007) hace ver que el espacio no puede ser pensado como algo vacío y pasivo, sino como producto de las relaciones social. Dice que es abstracto, real, práctico e ins- 
trumental, lo que lo diferencia del espacio mental y del espacio físico. Este espacio social contiene relaciones simbólicas que sirven para mantener las relaciones de producción y reproducción, así como representaciones de las relaciones de producción y de poder. El espacio de representación comprende el espacio vivido, relacional y social; encarna simbolismos complejos ligados a las resistencias simbólicas de la vida social como el arte.

Muchas veces el espacio pagano es convertido en espacio ritual, con determinadas prácticas y elementos reconocibles dentro del contexto cultural donde se genera. Según Zaira Salvador (2017, p. 43), el espacio es intervenido por elementos que lo dotan de sacralidad para ser transformado, explorado y utilizado por los intérpretes. Mediante la interrelación extracotidiana y la presencia de objetos sacros el espacio es enmarcado. Esta configuración responde a cánones bien marcados y a la presencia de elementos arquetípicos y simbólicos para la comunidad. En Tzintzuntzan, los espacios de uso cotidiano se convierten durante la Semana Santa en escenarios teatrales, dotados de gran significación cuando son ocupados para representar los lugres en los cuales se llevó a cabo la pasión, muerte y resurrección de Jesucristo. Los circuitos que recorren los fieles están configurados por espacios simbólicos de importancia, como los templos, cruces y casas donde se resguardan los cristos de los antiguos barrios que conformaron Tzintzuntzan en el siglo xVII.

Los mismos lugares donde se desarrollan las principales prácticas de la Semana Santa tienen usos muy variados en otras fechas. Durante la mayor parte del año, el atrio de los olivos es un espacio solitario y apacible, por donde transitan las personas de la localidad que acuden a los templos o que cruzan para dirigirse a distintos puntos de la ciudad; un par de niños ofrecen a los turistas una visita guiada por el exconjunto conventual a cambio de una propina, $y$ unos cuantos comerciantes se posan en la entrada principal para ofrecer sus productos. En un día común se pueden ver a personas sentadas en las bancas o en el césped, descansando o disfrutando de la tranquilidad del lugar. Los turistas que visitan el exconvento y los templos suelen permanecer poco tiempo en el sitio; recorren los edificios de interés, toman fotografías y se van. Los fines de semana el atrio es ocupado por niños que acuden al catecismo, mientras que en el templo parroquial se efectúan misas regulares o dedicadas a bodas, quince años, bautizos y primeras comuniones. Eventualmente se divisa pasar una caravana de personas cargando un difunto hacia el templo y del templo hacia el panteón. La rutina se rompe en algunos eventos multitudinarios, principalmente el día de muertos, la fiesta del Corpus y la 
fiesta del Señor del Rescate que, a diferencia de la Semana Santa, son fechas para bailar, comer, beber y divertirse con palos encebados y fuegos pirotécnicos; al tiempo que en otras partes del pueblo se acude a corridas de toros, bailes, peleas de gallos y muy diversas actividades.

En la época colonial el atrio era el lugar donde las multitudes indígenas, acostumbradas a realizar muchas de sus actividades rituales al exterior, se congregaban para oír misas al aire libre, aprender la doctrina cristiana y formar parte de las procesiones y danzas rituales; de cierta manera era una extensión del templo. Este gran espacio abierto también se utilizaba por las mañanas para el adoctrinamiento de los neófitos, en latín y lengua tarasca. Ahí se llevaba a cabo las fiestas y conmemoraciones más importantes, de acuerdo con el Tercer Concilio Provincial, entre las que destacaban la Semana Santa, el Corpus Christi, la Pascua, el Pentecostés y la Navidad.

Por su lado, el templo de San Francisco fue desde sus orígenes, y es, uno de los edificios con más significación para los fieles, ya que representa la casa de Dios, el lugar consagrado para recibir la sagrada Eucaristía y demás sacramentos. Espacial y simbólicamente es el corazón del poblado; el referente que da identidad y cohesión social; el lugar apropiado para orar, meditar, escuchar la palabra del Señor y, en general, participar del culto católico. El templo de la Soledad tiene prácticamente los mismos valores que el parroquial, o incluso más, por resguardar al Santo Entierro y otras imágenes de gran veneración para la comunidad de Tzintzuntzan. Los vestigios de la capilla de la Tercera Orden, como las capillas abiertas del exconvento y del hospital, son edificios que perdieron los usos originales y en la actualidad son poco utilizados durante el año, pero adquieren protagonismo en la Semana Santa, convirtiéndose en altares donde se colocan cruces e imágenes religiosas y donde se humillan los penitentes en sus recorridos.

Las calles se utilizan todo el año para transitar y distribuir a los diferentes lugares y edificios, marcar límites entre distintas zonas de la ciudad, para la interacción social y para realizar operaciones comerciales. Como ya se ha expuesto, durante la Semana Santa en Tzintzuntzan el espacio es delimitado y cobra ciertos matices con las actividades que realiza la gente. Las calles, caminos, espacios abiertos y cerrados cambian sus usos cotidianos y son percibidos por los sentidos. A través de los oídos, se captan los sonidos de los tambores, chirimías, silbatos de los espías, el roce de los grillos de acero, los golpes de los látigos en las espaldas de los penitentes, los cánticos, los rezos, los murmullos, los gritos y los quejidos, además de las campanas y matracas; 
el olfato detecta los aromas del incienso, las velas, las flores y la comida típica de la temporada, sin contar los que emana la gente; se pueden ver los colores de los brillantes trajes que usan los actores de la Judea, las telas moradas y negras que visten de luto las imágenes religiosas y el colorido de los altares y los cristos de pasta de caña; para los que participan en los rituales, el tacto se convierte en dolor cuando, en contraste con las suaves telas que cubren sus cinturas y rostros, los látigos de punta impactan sus espaldas, sus pies descalzos pisan las piedras de las calles, los grillos rozan sus tobillos, los lazos raspan sus puños, las pesadas cruces se posan en sus hombros, al igual que las bases de madera con las imágenes que son sacadas en procesión.

En Tzintzuntzan muchas de las prácticas han cambiado poco en décadas o siglos, pero el contexto urbano y las formas de vida actuales se han desajustado a las prácticas. Un ejemplo son los recorridos que hacen los espías el Miércoles y Jueves Santo para representar a los judíos enviados por el sanedrín para espiar a Jesús, o bien la búsqueda que hicieron los soldados romanos del nazareno. Esta práctica, que llegó a ser común en muchos poblados de México, sólo se realiza con esta cantidad de participantes y de la manera antes relatada en Tzintzuntzan, lo que es causa de gran interés por parte de los visitantes; no obstante, los jóvenes espías montados a caballo se arriesgan a ser víctimas de un accidente al avanzar entre los automóviles en movimiento. Pasa lo mismo con los penitentes, quienes además de lidiar con la temperatura, los empedrados, los grillos o la cruz sobre sus hombros, deben andar entre la muchedumbre y los automóviles. No es muy diferente en las procesiones que salen a la calle, pues estas vías no son cerradas en ningún momento. En el caso del Vía Crucis, que transcurre en el atrio, el riesgo es menor, pero debido a la cantidad de gente que se reúne para presenciar la representación de la Pasión de Cristo, los miembros de Judea, los espías y los cargueros tienen que formar una valla humana en todo el trayecto.

Uno de los aspectos que ha cambiado en las últimas décadas es el manejo de las actividades de la Semana Santa, ahora con fines turísticos y económicos. Hace unas cuantas décadas esta tradición era poco promocionada al exterior, hasta que su excepcionalidad fue vista por las autoridades $y$ la comunidad como una oportunidad para atraer visitantes y obtener dinero, al menos para solventar la inversión. Las limosnas de los fieles, depositadas en las alcancías de los templos y las que reciben los penitentes, son para la iglesia. Mientras tanto, los personajes que representan a Barrabás y a Judas, caminan por el poblado con una máscara en la cara, haciendo travesuras a la 
gente y recaudando dinero para apoyar con los gastos que hace la Judea, como lo es el vestuario de los actores. El resto de los gastos realizados por los cargueros, comisiones y los feligreses para arreglos, comida y otros menesteres no son recuperados.

Los eventos de esta semana son coordinados principalmente por la parroquia local, con ayuda de los cargueros, comisión de penitentes, comisión de la Judea y otros voluntarios. La promoción la hace principalmente la Secretaría de Turismo del Estado de Michoacán y la Dirección de Turismo y Cultura de Tzintzuntzan; en tanto que el Ayuntamiento local y el gobierno del estado coadyuvan en los temas de seguridad y protección civil. Desde luego que toman su lugar los comerciantes, artesanos y prestadores de servicios, organizándose para atender a los visitantes. La logística, por tanto, se vuelve compleja, ya que en muchos casos no se puede separar el tema religioso de lo civil y lo económico. Esta estrecha relación entre lo pagano y lo sagrado no es exclusiva de Tzintzuntzan ni es un fenómeno nuevo. Al igual que en la actualidad, en la mayoría de las celebraciones y fiestas de Nueva España era difícil distinguir los límites entre lo religioso y lo pagano. Tanto las autoridades seculares como eclesiásticas novohispanas tenían injerencia en las fiestas públicas como en las religiosas, por lo que muchas veces la frontera entre ambas festividades era inexistente. En distintos lugares las celebraciones litúrgicas eran acompañadas por gente con máscaras, carros alegóricos, paseos, comedias, corridas de toros, bailes, música, entre otros eventos; mientras que eventos de carácter cívico eran precedidas por misas y bendiciones (Jiménez, 2004, pp. 109-111).

A raíz del nombramiento de Tzintzuntzan como Pueblo Mágico, en 2012, la afluencia turística ha incrementado cada año, hasta superar los 20000 visitantes, que rebasa la capacidad de alojamiento y servicios disponibles. La amplia concurrencia de invitados es aprovechada por los vecinos para ofrecerles alimentos, montando puestos informales en la explanada que se encuentra al frente del atrio, en la plaza principal y a lo largo de la avenida principal. Igualmente improvisan estacionamientos y sanitarios públicos en terrenos y casas particulares, tal como sucede en la celebración del Día de Muertos.

Independiente a la comercialización de los rituales relacionados con la Semana Santa, hacia el interior del pueblo sigue existiendo una gran devoción, pero también hay quienes toman con poco respeto este periodo litúrgico. Algunas personas del lugar hacen notar que a diferencia de lo que sucede hoy en día, hace unas pocas décadas la gente de Tzintzuntzan se abste- 
nía de comer carne en los días santos, escuchar música, ver televisión, asistir a fiestas, divertirse y tener relaciones sexuales. Además de que la gente evitaba salir a la calle mientras los penitentes pasaban afuera de sus casas, por respeto o por temor, y si alguien llegaba a encontrase con uno se agachaba para no mirarlo. ${ }^{6}$ También era costumbre estrenar ropa esos días, por lo que las solemnidades se convertían en una oportunidad para mostrar pertinencia social o capacidad económica (Martínez, 2008, p. 91).

No dudamos que en el pasado la Semana Santa fuera para muchos un periodo de abstención, sacrificio, luto, reflexión y arrepentimiento, pero también debió haber personas que aprovechaban estos días de asueto para beber y convivir, como lo atestiguó Johnstone (1901) cuando visitó Tzintzuntzan, durante la Semana Santa. Para él, la conmemoración se había mezclado con una fiesta pagana (pp. 25-32). Pudo ver a los penitentes flagelantes, así como numerosas tiendas y puestos llenos de "indios en traje de fiesta", comiendo, bebiendo y alegrándose de celebrar el Jueves Santo. Cuando el extranjero se disponía a retratar la "maravillosa obra" del Descendimiento de Cristo que se encontraba en el templo parroquial, un grupo de individuos "con aliento a tequila y hablando un dialecto desconocido" lo golpearon fuertemente en la cabeza hasta dejarlo inconsciente. Al recobrar el conocimiento se encontró tirado, atado de pies y manos en un lugar oscuro, húmedo y maloliente, posiblemente dentro del exconvento.

Regresando a la actualidad, quienes manifiestan tener un gran respeto por las tradiciones y creencias ancestrales son los penitentes. El participar del rito de la penitencia puede ser una oportunidad para acercarse y estar en comunión con Dios, agradecer o pedir al Santo Entierro por milagros y bendiciones recibidas, por la salud de alguien -por ejemplo de los migrantes-, entre otras razones. La mayoría de los sacerdotes que son asignados a trabajar en Tzintzuntzan no están de acuerdo con que los fieles lastimen sus cuerpos, por lo que han intentado concientizarlos de que tal acción no es bien vista por la Iglesia y por Dios, pero al ser una tradición muy arraigada no han tenido éxito; por el contrario, los sacerdotes han tenido que adaptarse a los usos y costumbres de la comunidad.

Antonio Pérez, nacido en Tzintzuntzan, quien ha sido penitente, dice entender que Cristo no necesita que haga sacrificios o se lastime, pero los dolores corporales le ayudaron a comprender el sufrimiento que Jesús expe-

${ }^{6}$ Gabriela Rendón y Antonio Pérez Esquivel, comunicación personal, 4 de junio de 2019. 
rimentó, lo cual ha sido de utilidad para mejorar su propia vida. Además, considera que "si no se piden las cosas de corazón y se hace penitencia no son escuchados". ${ }^{7}$ Otro vecino de Tzintzuntzan considera que la gente tiene su fe y que la penitencia corporal es su manera de demostrar el amor y agradecimiento que tienen al Santo Entierro. ${ }^{8}$

\section{CONCLUSIONES}

En Tzintzuntzan, como sucede en muchos pueblos católicos, los espacios públicos que durante todo el año tienen usos profanos, en la Semana Mayor se transforman significativamente y se convierten en escenarios que representan los lugares donde Jesucristo pasó sus últimos días en la tierra, para después resucitar. No se limita a espacios reducidos, delimitados dentro de los muros de templos, capillas o del conjunto religioso, sino que una parte de la ciudad misma se convierte en el proscenio para la conmemoración de la pasión, muerte y resurrección de Jesús de Nazaret y en un circuito para el transitar de los penitentes. Lo interesante en esta comunidad es la supervivencia de ciertas prácticas que tienen códigos únicos y que han sido transmitidas por generaciones, que la diferencian de otros poblados donde los procesos de redefinición y reinterpretación del sentido práctico de la religión se ha separado con mayor claridad de la tradición institucional (Torre, 2013). Tal es el caso de los espías, quienes tienen un método complejo para recorrer las calles de la ciudad y buscar simbólicamente a Jesús, de manera coordinada, siguiendo ciertas reglas, que son parte de sus usos y costumbres. Desde luego, caso excepcional son los recorridos y rituales que hacen los numerosos penitentes de grillos y cruces, quienes siguen mortificando sus cuerpos con látigos de puntas, mientras que sus muñecas y tobillos se laceran por los lazos y grillos que los aprietan durante los recorridos. Únicos son también los recorridos que hacen en el atrio y en la ciudad, siguiendo reglas determinadas por la tradición, que denotan un complejo simbolismo. El ritual está colmado de una serie de condicionantes que no pueden descuidar, ya que de no seguir los códigos establecidos tradicionalmente la manda tiene que repetirse o perder

\footnotetext{
7 Antonio Pérez Esquivel, comunicación personal, 4 de junio de 2019.

8 José Rendón, comunicación personal, 4 de junio de 2019.
} 
validez. Las razones que los motivan a tal pena, según testimonios, provienen de la enorme devoción que le tienen al cristo del Santo Entierro.

Aunque de un año a otro se pueden introducir elementos nuevos a las prácticas, como detalles en las vestimentas, el número de participantes o el empleo de nueva tecnología, en general se conserva la esencia de las mismas. La descripción que hace Foster (2000) de las prácticas de la Semana Santa en 1945 en comparación con las de la actualidad, da cuenta de que son menos los cambios que la continuidad de las mismas -a pesar de la introducción de otras religiones, como advertía Cahn (2003)-. El antropólogo estadunidense atribuye este fenómeno a la ubicación geográfica que tiene esta ciudad michoacana "en el corazón de las más fuertes y fanáticas regiones católicas de México" (pp. 271-272). Sospechamos -y un estudio más detallado puede dar más respuestas- que otros aspectos, como las estrechas relaciones sociales que mantienen los tzintzuntzeños entre sí, la buena organización de la comunidad para llevar a cabo actividades colectivas, una comunicación efectiva, el sentido de pertenencia comunitario, donde aspectos como el prestigio social es un componente clave, son también razones que contribuyen a que todos estén dispuesto a participar en las actividades religiosas y conozcan cómo deben llevarse a cabo para continuar la tradición.

La teatralización de todas las ceremonias relacionadas con la pasión, muerte y resurrección de Cristo fue históricamente una forma de evangelizar y despertar devoción en la época colonial. En la actualidad tiene la misma intención: la dramatización de los misterios, la escenografía, el vestuario de los participantes, la iluminación, los sonidos, ya sea con cánticos e instrumentos musicales, incluso el olor de las veladoras, las flores y el incienso, que logran emocionar a los asistentes y mantienen vivo el interés de los mismos. Además de la verdadera devoción de los participantes y la intención de la Iglesia de conmemorar los acontecimientos que soportan parte de la fe católica, la derrama erogada por los turistas y los fieles vecinos es un aliciente adicional para que organismos gubernamentales estatales y prestadores de servicios tengan interés en la conservación de estas interesantes representaciones. 


\section{LISTA DE REFERENCIAS}

Bechtloff, D. (1996). Las cofradías en Michoacán durante la época de la colonia. La religión y su relación política y económica en una sociedad intercultural. Zinacantepec: El Colegio de Michoacán/El Colegio Mexiquense.

Benavente, T. (1979). Historia de los indios de la Nueva España. México: Porrúa.

Cahn, P. (2003). All religions are good in Tzintzuntzan: Evangelicals in catholic Mexico. Austin: University of Texas Press.

Carrillo, A. (1992). Partidos y padrones del obispado de Michoacán 1680-1685. Zamora: El Colegio de Michoacán/Gobierno del Estado de Michoacán.

Certeau, M. (2007). La invención de lo cotidiano (vol. I). México: Instituto Tecnológico y de Estudios Superiores de Occidente/Universidad Iberoamericana.

Ciudad Real, A. (1976). Tratado curioso y docto de las grandezas de la Nueva España. Relación breve y verdadera de algunas cosas de las muchas que sucedieron al padre fray Alonso Ponce [...]. (2 vols.). México: J. García y V. Castillo (eds.).

Foster, G. (2000). Los hijos del imperio, la gente de Tzintzuntzan. Zamora: el Colegio de Michoacán.

Iglesias, M. (2003). Nuevo Testamento. Madrid: Encuentro.

Jiménez, J. (2004). Creencias y práctica religiosas en Querétaro al final de la colonia. En J. Jiménez, Creencias y prácticas religiosas en Querétaro. Siglos XVI-XIX. Querétaro: Plaza y Valdés.

Johnstone, B. (1901). Entombment, by Titian. My adventures when trying to photograph it. The Wide World Magazine, 6, 25-31.

Lefebvre, H. (2007). The production of space. Oxford: Blackwell Publishers.

López de Gómara, F. (2007). Prólogo y bibliografía J. Gurría. En Historia de la conquista de México. Caracas: Fundación Biblioteca Ayacuho.

Martiarena, Ó. (1999). Culpabilidad y resistencia. Ensayo sobre la confesión en los indios de la Nueva España. México: Universidad Iberoamericana.

Martínez, J. (2016a). El Tiziano de Tzintzuntzan. El lienzo que se volvió leyenda. Signos Históricos, 18(36), 80-117. Recuperado de https://signoshistoricos.izt.uam. $\mathrm{mx} /$ index.php/historicos/article/view/486

Martínez, J. (2016b). La secularización del convento franciscano de Tzintzuntzan, resistencia de un pueblo. Tzintzun, 64, 69-91. Recuperado de http://www.scielo. org.mx/scielo.php?script=sci_arttext\&pid=S1870-719X2016000200069\&ln$\mathrm{g}=\mathrm{es} \& \ln \mathrm{ln}=\mathrm{es}$ 
Martínez, J. (2017a). Las cofradías novohispanas de Tzintzuntzan. Bienes, prácticas y espacios de devoción. Relaciones. Estudios de Historia y Sociedad, 38(51), 11-57. DoI: http://dx.doi.org/10.24901/rehs.v38i151.327

Martínez, J. (2017b). Reacomodos de población en Tzintzuntzan durante el siglo XVI. Secuencia, 97, 6-29. DoI: https://doi.org/10.18234/secuencia.v0i97.1446

Martínez, L. J. (2008). La Semana Santa en el México decimonónico a través de los viajeros extranjeros. (Tesis de licenciatura). Universidad Nacional Autónoma de México/ Facultad de Filosofía y Letras, México.

Palomero, J. (1981). Las procesiones de sangre en Sevilla y Nueva España. A propósito de una pintura mural en la iglesia conventual de Huexotzingo. Primeras Jornadas de Andalucía y América, 2, 313-320.

Phillips, R. (1999). La participación de los indígenas en las procesiones por los claustros del siglo XVi en México. Relaciones, 20(78), 227-250.

Rea, A. de la (1643). Chronica de la Orden de N. Seraphico P. S. Francisco, provincia de S. Pedro y S. Pablo de Mechoacan en la Nueva España. México: Viuda de Bernardo Calderón.

Rendón, A. (1996). Tzintzuntzan, monografía municipal. Morelia: Gobierno del Estado de Michoacán/H. Ayuntamiento de Tzintzuntzan.

Rendón, A. (1998). Semana Santa en Michoacán. Morelia: Fondo Estatal para la Cultura y las Artes de Michoacán.

Ricard, R. (1992). La conquista espiritual de México. México: Fondo de Cultura Económica.

Rodríguez, P. (dir.) (2006). Tzintzuntzan Semana Santa [documental]. Producción independiente.

Salvador, Z. (2017). Estudio de la representación de Semana Santa en San Pedro Atlapulco, Edo. Mex. (Tesis de licenciatura). Universidad Nacional Autónoma de México, México.

Torquemada, J. (1983). Monarquía indiana (7 vols.). Miguel León Portilla (ed.). México: Instituto de Investigaciones Históricas-Universidad Nacional Autónoma de México.

Torre, E. (1971). La ciudad de México en varios testimonios. México: Universidad Autónoma de Nuevo León.

Torre, R. de la (2013). La religiosidad popular encrucijada de las nuevas formas de la religiosidad contemporánea y la tradición (el caso de México). Ponto Urbe, 12. DoI: https://doi.org/10.4000/pontourbe.581

Urquiza, G. (1993). Convento Huexotla, reflejo de la mística franciscana. México: Plaza y Valdés. 
Verdi, S. (1995). La cofradía de la Vera-Cruz representada en las pinturas murales de Huexotzingo. Laboratorio, 8, 61-72.

Warren, B. (1997). Vasco de Quiroga y sus Pueblos Hospitales de Santa Fe. México: Ediciones Hidalgo/Universidad Michoacana de San Nicolás de Hidalgo.

Wright, D. (1998). Los franciscanos y su labor educativa en la Nueva España (1523-1580). México: Instituto Nacional de Antropología e Historia/Editorial de la Universidad del Valle de México (Colección Divulgación).

\section{OTRAS FUENTES}

Archivos

AGN Archivo General de la Nación, México.

AHCM Archivo Histórico Casa de Morelos, Morelia, Michoacán, México.

Cенm CarsoCentro de Estudios de Historia de México Carso, México. 